\title{
Assessing Ploidy Level Analysis and Single Pollen Genotyping of Diploid and Euploid Citrus Genotypes by Fluorescence-Activated Cell Sorting and Whole-Genome Amplification
}

\author{
Miguel Garavello ${ }^{1,2}$, José Cuenca ${ }^{1}$, Steven Dreissig ${ }^{3}$, Jörg Fuchs ${ }^{3}$, Andreas Houben ${ }^{3}$ \\ and Pablo Aleza ${ }^{1 *}$ \\ ${ }^{1}$ Centro de Citricultura y Producción Vegetal, Instituto Valenciano de Investigaciones Agrarias (IVIA), Moncada, Valencia, \\ Spain, ${ }^{2}$ INTA, Concordia Agricultural Experiment Station, Concordia, Argentina, ${ }^{3}$ Department of Breeding Research, Leibniz \\ Institute of Plant Genetics and Crop Plant Research (IPK) Gatersleben, Seeland, Germany
}

OPEN ACCESS

Edited by:

Inaki Hormaza,

Institute of Subtropical and Mediterranean Hortofruticultura La

Mayora (IHSM), Spain

Reviewed by:

Gaetano Distefano,

University of Catania, Italy

Wen-Wu Guo,

Huazhong Agricultural University,

China

${ }^{*}$ Correspondence:

Pablo Aleza

aleza@ivia.es

Specialty section: This article was submitted to

Plant Breeding,

a section of the journal

Frontiers in Plant Science

Received: 05 July 2019

Accepted: 27 August 2019

Published: 24 September 2019

Citation:

Garavello M, Cuenca J, Dreissig S,

Fuchs J, Houben A and Aleza $P$

(2019) Assessing Ploidy Level

Analysis and Single Pollen Genotyping of Diploid and Euploid Citrus Genotypes by FluorescenceActivated Cell Sorting and Whole-

Genome Amplification.

Front. Plant Sci. 10:1174.

doi: 10.3389/fp/s.2019.01174
Flow cytometry is widely used to determine genome size and ploidy level in plants. This technique, when coupled with fluorescence-activated cell sorting (FACS), whole genome amplification and genotyping (WGA), opens up new opportunities for genetic studies of individualized nuclei. This strategy was used to analyze the genetic composition of single pollen nuclei of different citrus species. The flow cytometry and microscope observations allowed us to differentiate the populations of pollen nuclei present in the diploid and euploid genotypes analyzed, showing that citrus has binuclear pollen. We have identified in the "CSO" tangor an additional nuclei population composed by the vegetative plus generative nuclei. Genotyping of this nuclei population revealed that vegetative and generative nuclei show the same genetic configuration. In addition, we have demonstrated the presence of unreduced gametes in the diploid genotype "Mexican lime." Genomic amplification is a robust method for haploid nuclei genotyping with several molecular markers, whereas in diploid nuclei using heterozygous markers showed a bias towards one of the two alleles, limiting the use of this tool in this type of nuclei. We further discuss the importance and applications of single pollen genotyping in citrus genetic studies.

Keywords: flow cytometry, triploid, tetraploid, fluorescence-activated cell sorting, whole genome amplification, SSR and SNP markers, unreduced gametes

\section{INTRODUCTION}

Flow cytometry has become a widely used technique for genome size estimation and ploidy analysis in plant research because of its high throughput, accuracy and resolution as well as low operating cost per sample. Fluorescence-activated cell sorting (FACS) enables the separation of nuclei according to their optical properties. The direct analysis of individual nuclei is generally limited by their low amount of DNA (Hou et al., 2015). To circumvent this problem Whole Genome Amplification (WGA) can be applied. WGA is a method for the robust amplification of a complete genome, starting with nanogram DNA quantities and resulting in microgram quantities of the amplified products (de Bourcy et al., 2014; Dreissig et al., 2015; Gawad et al., 2016). A critical step in WGA is the minimization of the amplification bias, generation of mutations and chimeras. In 
this sense, isothermal methods such as Multiple Displacement Amplification (MDA) have demonstrated to introduce a low error rate (Gawad et al., 2016).

Beside the application of leaves, young stems, flowers, roots, and seeds, also mature pollen grains collected from anthers of several herbaceous and woody species have been used for flow cytometry analysis (Van Tuyl et al., 1989; Bino et al., 1990; Zhang et al., 1992; Mishiba et al., 2000; Pichot and El Maâtaoui, 2000; Pan et al., 2004; Stehlik et al., 2007; Kron and Husband, 2012; Chung et al., 2013; Dreissig et al., 2017). Angiosperm pollen contains both vegetative and generative sperm nuclei, which can be structurally and morphologically different (Van Tuyl et al., 1989; Bino et al., 1990; Dewitte et al., 2009). The genotyping of individualized pollen grain nuclei opens up new opportunities in different areas of research such as the ecology of pollination, genetic, and genomic studies (Isagi and Suyama, 2010). In addition, genotyping of individual pollen grains can be useful for the determination of the haplotypes of the male parent and meiotic recombination patterns (Mase et al., 2014; Dreissig et al., 2017) and also allows performing studies on the genetic structures of pollen grain populations as compared with those originated at the plant level, without interferences due to a potential cross-incompatibility (Gu et al., 2013). However, to our knowledge, ploidy level analysis and genotyping of pollen grains have not been previously assessed in citrus.

Diploid genotypes are the most common one in Citrus and related genera, with a basic chromosome number of $x=9$ (Krug, 1943); although euploids and aneuploids have been induced or found occasionally, with triploids and tetraploids being the most common euploid variations (Lee, 1988). The genus Citrus can be used as a model for the study of somatic and sexual polyploidization (Ollitrault et al., 2008; Aleza et al., 2009a; Aleza et al., 2009b; Cuenca et al., 2015a; Aleza et al., 2016). Sexual polyploidization by the formation of female unreduced gametes is a relatively frequent event in citrus and it is routinely used to obtain triploid hybrids through hybridizations between diploid progenitors (Aleza et al., 2010; Cuenca et al., 2011; Cuenca et al., 2015a; Cuenca et al., 2015b; Rouiss et al., 2017b). The formation of unreduced pollen grains in citrus has been also reported from the genetic analysis of tetraploid populations (Rouiss et al., 2017a) and the direct observation and handmade isolation of large pollen grains of one diploid genotype, associated with unreduced gametes (Honsho et al., 2016). In order to improve the efficiency of citrus triploid breeding based on sexual hybridizations between diploid parents, it would be of great interest to develop a simple methodology that allows the ploidy level analysis of mature pollen grains for identifying parents producing unreduced pollen grains. In addition, this methodology would also increase the knowledge about the viability of citrus triploid hybrids pollen grains.

On the other hand, there is a lack of knowledge about citrus pollen genotyping. A limiting factor of this technique is the small amount of DNA per pollen and, thus, limiting the number of markers that can be used for analyzing single pollen grains (Matsuki et al., 2007; Martin et al., 2019). Citrus pollen genotyping has been previously only performed by multiplex PCR (Honsho et al., 2016). In the present study, we describe an effective methodology to determine the ploidy level in mature pollen grains of diploid, triploid, and tetraploid citrus genotypes, using FACS, followed by WGA and genotyping of individualized nuclei from pollen grains by Simple Sequence Repeats (SSR) and Single Nucleotide Polymorphism (SNP) molecular markers. Finally, we discuss the applications and implications of flow cytometry to determine the ploidy level of citrus pollen grains populations and the use of FACS combined with WGA for the genotyping of individualized nuclei.

\section{MATERIALS AND METHODS}

\section{Plant Material}

A total of 59 genotypes of different Citrus species and ploidy levels (1 haploid, 45 diploid, 7 triploid, and 6 tetraploid genotypes) were used from the pathogen-free Germplasm Bank (Navarro et al., 2002) (Table 1) of the Instituto Valenciano de Investigaciones Agrarias (IVIA) located at Moncada (Valencia, Spain).

Between 40 and 50 flowers in pre-anthesis were collected from each genotype from the four cardinal points of the tree during Spring 2018. The anthers were removed from the flowers and placed in Petri dishes (50-80 anthers/plate, 16-25 plates/ genotype) inside a desiccator containing silica gel until the anthers opened within 24-48 h. Petri dishes containing fully dehisced anthers were then sealed with parafilm and stored at $-20^{\circ} \mathrm{C}$ until use (Volk, 2011).

\section{Pollen Nuclei Isolation and Ploidy Level Analysis}

Flow cytometry was used to determine the ploidy level of the control leaves and mature pollen grains. As controls, we used leaves of haploid and diploid clementine (Citrus clementina Hort. ex Tan.). Leaf samples were chopped using a razor blade in the presence of a nuclei isolation buffer (Galbraith et al., 1983). Nuclei were filtered through a $30 \mu \mathrm{m}$ nylon filter and stained with DAPI $(1.5 \mu \mathrm{g} / \mathrm{ml})$. After $10 \mathrm{~min}$ incubation, stained samples were run on a BD Influx (BD Biosciences, USA) and analyzed with BD FACS software.

To determine the pollen size, pollen from fully dehisced anthers were distributed with a brush onto a microscope slide. Preparations were observed under a Leica DMLS microscope and the diameters of 200 mature pollen grains were measured using the ImageJ2 software (Schindelin et al., 2015). To analyze the ploidy level of mature pollen grains, pollen nuclei were isolated as described by Kron and Husband (2012). The mesh size of the pre-filter and bursting filter was 50 and $20 \mu \mathrm{m}$, respectively. Afterwards, 4-5 dehisced anthers were collected in a $1.5 \mathrm{ml}$ tube adding $300 \mu \mathrm{l}$ of nuclei isolation buffer. The suspension was vortexed to release all pollen grains. The suspension was then filtered using the pre-filter and the bursting filter (CellTrics ${ }^{\circledR}$ filters, Partec ${ }^{\circledR}$ ). The bursting filter, with the collected pollen grains, was then placed inside a clean tube and the pollen grains were gently rubbed against the filter for 10-15 s, using a plastic rod. Nuclei were rinsed through the filter with nuclei isolation buffer, and the process was repeated twice. After adding DAPI $(1.5 \mu \mathrm{g} / \mathrm{ml})$ the suspension was incubated for $10 \mathrm{~min}$ on ice and run on the cytometer as described before. 
TABLE 1 | Citrus genotypes used to measure the relative DNA content of pollen grains by flow cytometry.

\begin{tabular}{|c|c|c|c|}
\hline $\begin{array}{l}\text { Ploidy } \\
\text { level }\end{array}$ & Genotype & ${ }^{\star}$ Species & $\begin{array}{c}\text { Bank } \\
\text { ID }\end{array}$ \\
\hline $1 X$ & Haploid clementine & C. clementine & IVIA-638 \\
\hline $2 X$ & N’15 mandarin & C. hybrid & - \\
\hline $2 X$ & CSO tangor & C. hybrid & - \\
\hline $2 x$ & Hamlin sweet orange & C. sinensis & IVIA-010 \\
\hline $2 X$ & Pineapple sweet orange & C. sinensis & IVIA-011 \\
\hline $2 X$ & Wilking mandarin & C. reticulate & IVIA-028 \\
\hline $2 X$ & Sanguinelli blood orange & C. sinensis & IVIA-034 \\
\hline $2 x$ & Fina clementine & C. clementine & IVIA-039 \\
\hline $2 X$ & Fino 74-L-08 lemon & C. limon & IVIA-049 \\
\hline $2 X$ & Verna lemon & C. limon & IVIA-062 \\
\hline $2 X$ & Fortune mandarin & C. reticulate & IVIA-080 \\
\hline $2 x$ & Temple tangor & C. temple & IVIA-081 \\
\hline $2 X$ & Fairchild mandarin & C. reticulate & IVIA-083 \\
\hline $2 X$ & Seville sour orange & C. aurantium & IVIA-117 \\
\hline $2 X$ & Olinda sweet orange & C. sinensis & IVIA-127 \\
\hline $2 X$ & Mexican lime & C. aurantifolia & IVIA-164 \\
\hline $2 X$ & Marsh grapefruit & C. paradise & IVIA-176 \\
\hline $2 X$ & Campeona mandarin & C. nobilis & IVIA-193 \\
\hline $2 X$ & Ellendale tangor & C. reticulate & IVIA-194 \\
\hline $2 X$ & Murcott tangor & C. reticulate & IVIA-196 \\
\hline $2 X$ & Star Ruby grapefruit & C. paradise & IVIA-197 \\
\hline $2 X$ & Fingered citron & C. medica & IVIA-202 \\
\hline $2 X$ & Chandler pummelo & C. maxima & IVIA-207 \\
\hline $2 X$ & Limoneira Lisbon lemon & C. limon & IVIA-214 \\
\hline $2 X$ & Frost navel orange & C. sinensis & IVIA-222 \\
\hline $2 X$ & Tachibana & C. tachibana & IVIA-237 \\
\hline $2 X$ & Duncan grapefruit & C. paradise & IVIA-274 \\
\hline $2 X$ & Pink pummelo & C. maxima & IVIA-275 \\
\hline $2 X$ & Ortanique tangor & C. reticulate & IVIA-276 \\
\hline $2 X$ & Río Red grapefruit & C. paradise & IVIA-289 \\
\hline $2 x$ & Eureka Frost lemon & C. limon & IVIA-297 \\
\hline $2 X$ & Palestine sweet lime & C. limettioides & IVIA-305 \\
\hline $2 X$ & Gil pummelo & C. maxima & IVIA-321 \\
\hline $2 X$ & Bernalina sweet orange & C. sinensis & IVIA-331 \\
\hline $2 X$ & Rough lemon & C. jambhiri & IVIA-333 \\
\hline $2 X$ & Rangpur lime & C. limonia & IVIA-334 \\
\hline $2 x$ & Seminole tangelo & C. hybrid & IVIA-348 \\
\hline $2 X$ & Willow leaf mandarin & C. deliciosa & IVIA-383 \\
\hline $2 x$ & Carrizo citrange & C. sinensis $\times$ P. trifoliata & IVIA-387 \\
\hline $2 X$ & Anana mandarin & C. reticulata & IVIA-390 \\
\hline $2 x$ & $\begin{array}{c}\text { Tarocco Rosso blood } \\
\text { orange }\end{array}$ & C. sinensis & IVIA-392 \\
\hline $2 X$ & Moncada mandarin & C. hybrid & IVIA-421 \\
\hline $2 X$ & Alemow & C. macrophylla & IVIA-518 \\
\hline $2 X$ & Corsican citron & C. medica & IVIA-567 \\
\hline $2 X$ & Imperial mandarin & C. reticulata & IVIA-576 \\
\hline $2 X$ & Nadorcott mandarin & C. reticulata & IVIA-641 \\
\hline $3 x$ & CidMexT 99-7 & C. hybrid & - \\
\hline $3 X$ & Oroblanco & C. maxima $\times$ C. paradisi & IVIA-302 \\
\hline $3 x$ & Safor mandarin & C. hybrid & IVIA-581 \\
\hline $3 X$ & Alborea mandarin & C. hybrid & IVIA-592 \\
\hline $3 X$ & Coral mandarin & C. hybrid & IVIA-593 \\
\hline $3 X$ & Tania 46 mandarin & C. hybrid & IVIA-594 \\
\hline $3 x$ & Matiz mandarin & C. hybrid & IVIA-595 \\
\hline $4 X$ & Chandler pummelo & C. maxima & - \\
\hline $4 X$ & Nadorcott mandarin & C. reticulata & - \\
\hline $4 X$ & Moncada mandarin & C. hybrid & - \\
\hline $4 X$ & Eureka lemon & C. limon & IVIA-495 \\
\hline $4 X$ & Cleopatra mandarin & C. reshni & IVIA-502 \\
\hline $4 X$ & Alemow & C. macrophylla & IVIA-518 \\
\hline
\end{tabular}

*The name of the species is based on the Tanaka classification (Tanaka, 1954; Tanaka, 1977).

\section{FACS-Based Purification of Single Nuclei and Whole Genome Amplification}

FACS-based purification of single nuclei and WGA was carried out following the methodology described by Dreissig et al. (2015). From the nuclei suspension, single nuclei were sorted using a $\mathrm{BD}$ Influx cell sorter (BD Biosciences, USA) into individual wells of a 384-microwell plate containing $2 \mu \mathrm{l}$ lysis solution, which was composed of $0.5 \mu \mathrm{l}$ lysis buffer, $0.5 \mu \mathrm{lddH} 2 \mathrm{O}$ and $1 \mu \mathrm{l}$ sample buffer (Genomiphi V2, GE Healthcare).

To control the nuclear composition of the individual peaks, nuclei from the different fractions were sorted onto microscopic slides and checked under a fluorescence microscope Axioplan2 (ZEISS, Jena, Germany) equipped with an ORCA-ER CCD camera (Hamamatsu, Japan). Pictures were taken using the Simple PCI (Compix Inc., Imaging Systems, USA) software.

WGA was performed using the Illustra GenomiPhi V2 DNA Amplification Kit (GE Healthcare, USA). Nuclei lysis and DNA denaturation were conducted by incubation at $65^{\circ} \mathrm{C}$ for $3 \mathrm{~min}$ in $2 \mu \mathrm{l}$ lysis solution. The lysis solution was neutralized by adding $0.5 \mu$ neutralization buffer $(666 \mathrm{mM}$ Tris- $\mathrm{HCl}$, $250 \mathrm{mM} \mathrm{HCl}$ ). Afterwards, a master mix composed of $3.5 \mu \mathrm{l}$ sample buffer, $4.5 \mu \mathrm{l}$ reaction buffer and $0.5 \mu \mathrm{l}$ enzyme mix (Genomiphi V2, GE Healthcare) per reaction was added and samples were incubated at $30^{\circ} \mathrm{C}$ for $8 \mathrm{~h}$ followed by inactivation of the enzyme at $65^{\circ} \mathrm{C}$ for $10 \mathrm{~min}$. Subsequently, each sample was diluted with $500 \mu \mathrm{lddH} 2 \mathrm{O}$. The DNA concentration of the WGA products was measured by fluorometric quantitation (Qubit, Life Technologies). Additionally, several single pollen nuclei of the genotypes subjected to WGA were mixed in the same well to be used as a positive control against amplification errors (Dreissig et al., 2015).

\section{Genotyping With Molecular Markers}

WGA pollen DNA and genomic leaf DNA were genotyped with SSR and SNP molecular markers displaying heterozygosity for the analyzed genotypes (Table 2). These markers are distributed across all linkage groups (LGs) of the clementine genetic map (Ollitrault et al., 2012). Genomic DNA from control leaves was isolated using a Plant DNeasy kit from Qiagen Inc. (Valencia, CA, USA) following the manufacturer's protocol.

PCR amplification using SSR markers was performed using a Thermocycler rep gradient $S$ (Eppendorf ${ }^{\circledR}$ ) in $15 \mu \mathrm{l}$ containing $0.5 \mu \mathrm{l} 1 \mathrm{U} / \mu \mathrm{l}$ of Taq DNA polymerase (Fermentas $\left.{ }^{\circledR}\right), 3 \mu \mathrm{l}$ citrus DNA, $1.5 \mu \mathrm{l}$ of $2 \mathrm{mM}$ welled $\left(\mathrm{Sigma}^{\circledR}\right)$ dye-labeled forward primer, $1.5 \mu \mathrm{l}$ of $2 \mathrm{mM}$ non-dye-labeled reverse primer, 0.2 mM of each dNTP, $1.5 \mu \mathrm{l}$ 10X PCR buffer, and $0.45 \mu \mathrm{l} 50 \mathrm{mM}$ $\mathrm{MgCl}_{2}$. The PCR protocol was as follows: denaturation at $94^{\circ} \mathrm{C}$ for $5 \mathrm{~min}$ followed by 40 cycles of $30 \mathrm{~s}$ at $94^{\circ} \mathrm{C}, 30 \mathrm{~s}$ at 50 or $55^{\circ} \mathrm{C}$, and $30 \mathrm{~s}$ at $72^{\circ} \mathrm{C}$; and a final elongation step of $8 \mathrm{~min}$ at $72^{\circ} \mathrm{C}$. Capillary electrophoresis was carried out using a Genetic Analysis System 8000 (Beckman Coulter Inc.). The PCR products were initially denatured at $90^{\circ} \mathrm{C}$ for 2 min, injected at $2 \mathrm{kV}$ for $30 \mathrm{~s}$, and separated at $6 \mathrm{kV}$ for $35 \mathrm{~min}$. Alleles were sized based on a DNA size standard (400 bp). GenomeLab ${ }^{\mathrm{TM}}$ v.10.0 (Beckman Coulter Inc.) genetic analysis software was used for data collection. 
TABLE 2 | Information about the molecular markers used in citrus pollen grain and leaf nuclei genotyping, including GenBank accession numbers, genetic distances, noted alleles and bibliographic references.

\begin{tabular}{|c|c|c|c|c|c|c|c|c|}
\hline Genotype & Locus & $\begin{array}{l}\text { Gene bank/ } \\
\text { phytozome } \\
\text { accesion }\end{array}$ & $\begin{array}{c}\text { Marker } \\
\text { type }\end{array}$ & $\begin{array}{l}\text { Linkage } \\
\text { group }\end{array}$ & $\begin{array}{c}\text { Genetic } \\
\text { map locus } \\
\text { position (cM) }\end{array}$ & $\begin{array}{l}\text { Distance } \\
\text { to the } \\
\text { centromere } \\
\text { (cM) }\end{array}$ & $\begin{array}{l}\text { Noted } \\
\text { alleles }\end{array}$ & Reference \\
\hline \multirow[t]{8}{*}{ CSO tangor } & CIBE6147 & ET085226 & SSR & 1 & 2.69 & 57.97 & 204-212 & Ollitrault et al. (2010) \\
\hline & 2P21022555 & Ciclev10018135 m.g & SNP & 2 & 57.00 & 0.10 & A:T & Curk et al. (2015) \\
\hline & MEST470 & DY290454 & SSR & 3 & 88.76 & 1.83 & $254-258$ & In preparation \\
\hline & CF-ACA01 & CN181701.1 & SSR & 4 & 24.41 & 8.30 & $335-338$ & In preparation \\
\hline & MEST15 & FC912829 & SSR & 5 & 16.21 & 6.91 & 174-192 & García-Lor et al. (2012) \\
\hline & CiC4356-06 & ET111465 & SNP & 6 & 6.21 & 0.20 & C:T & Ollitrault et al. (2012) \\
\hline & mCrCIR03B07 & FR677573 & SSR & 7 & 83.39 & 13.04 & 263-265 & Cuenca et al. (2011) \\
\hline & LCY2-M-379 & FJ516403 & SNP & 8 & 58.10 & 3.90 & $A: G$ & Ollitrault et al. (2012) \\
\hline \multirow[t]{3}{*}{ Carrizo citrange } & SOS1-M50 & JX630068 & SNP & 1 & 78.51 & 17.85 & $A: G$ & Garcia-Lor et al. (2013a) \\
\hline & PSY-M30 & JX630080 & SNP & 6 & 69.72 & 63.52 & $C: G$ & Garcia-Lor et al. (2013a) \\
\hline & FLS-P129 & JX630083 & SNP & 7 & 45.99 & 50.44 & C:T & Garcia-Lor et al. (2013a) \\
\hline \multirow[t]{3}{*}{ Eureka Frost lemon } & CiC2110-02 & ET099643 & SNP & 1 & 29.61 & 31.05 & $A: C$ & Ollitrault et al. (2012) \\
\hline & CiC3712-01 & ET079481 & SNP & 2 & 93.92 & 37.05 & $A: C$ & Ollitrault et al. (2012) \\
\hline & CiC1459-02 & ET073328 & SNP & 3 & 118.06 & 27.47 & $A: C$ & Ollitrault et al. (2012) \\
\hline \multirow[t]{3}{*}{ Moncada mandarin } & ClC2810-01 & ET103230 & SNP & 1 & 63.40 & 2.7 & $A: C$ & Ollitrault et al. (2012) \\
\hline & INVA-P855 & JX630071 & SNP & 3 & 30.21 & 60.37 & C:T & Garcia-Lor et al. (2013a) \\
\hline & LAPXCF238 & EU719653 & SNP & 6 & 19.16 & 12.96 & $\mathrm{G}: \mathrm{C}$ & Ollitrault et al. (2012) \\
\hline \multirow[t]{3}{*}{ Mexican lime } & ClC6213-07 & ET085253 & SNP & 4 & 84.57 & 61.45 & $\mathrm{G}: A$ & Ollitrault et al. (2012) \\
\hline & ClC4356-06 & ET107540 & SNP & 6 & 6.15 & 0.05 & C:T & Ollitrault et al. (2012) \\
\hline & CHI-M598 & JX630075 & SNP & 4 & 11.03 & 5.13 & $C: G$ & Garcia-Lor et al. (2013a) \\
\hline
\end{tabular}

SNP markers were genotyped using KASPar ${ }^{\mathrm{TM}}$ technology by LGC Genomics (Hoddesdon, UK). The KASPar ${ }^{\mathrm{TM}}$ Genotyping System is a competitive, allele-specific dual Förster resonance energy transfer (FRET)-based assay for SNP genotyping. Primers were directly designed by LGC Genomics based on the SNP locus flanking sequence. A detailed explanation of the specific conditions and reagents using the KASPar technique can be found in Cuppen (2007).

In order to test if WGA of diploid nuclei is an adequate approach to identify unreduced gametes, 10 individualized nuclei from leaves of "Carrizo" citrange, "Eureka" lemon, "Mexican" lime, and "Moncada" mandarin were isolated and amplified. As positive controls, DNA from leaves and 20 leaf nuclei were isolated from each genotype in the same well. WGA products were evaluated using three different heterozygous SNPs markers for each genotype located in different LGs.

\section{RESULTS}

\section{Ploidy Level of Mature Pollen Grains of Diploid, Triploid, and Tetraploid Citrus Genotypes}

To isolate the nuclei of mature citrus pollen grains for flow cytometric measurements of the DNA content a practical and efficient protocol is needed. For this purpose, we tested different methodologies reported in the literature, including mechanical crushing (Galbraith et al., 1983) and sonication (Dewitte et al., 2009). However, these approaches resulted in high levels of background and no conspicuous and reliable peaks were detected in the histograms (data no shown). Only the "bursting" methodology proposed by Kron and Husband (2012) resulted in clear DNA peaks. To determine the necessary diameters of the pre- and bursting filters required for the pollen grain and nuclei isolation, respectively, we measured the diameters of pollen grains of 10 different citrus genotypes representing ancestral and secondary species. Figure 1 shows selected examples of pollen grain size measurements of the cultivars "Corsican" citron, "Fortune" mandarin and "Mexican" lime. The populations of pollen grains showed a unimodal distribution, with slight differences in sizes between genotypes. The diameters of "Corsican" citron pollen grains ranged from 26 to $40 \mu \mathrm{m}$, between 22 and $36 \mu \mathrm{m}$ for "Fortune" mandarin and "Mexican" lime showed a size distribution between 22 and $50 \mu \mathrm{m}$ (Figure 1). The minimum diameter value observed was $22 \mu \mathrm{m}$ and the maximum value was $50 \mu \mathrm{m}$; therefore, we decided to work with the $50 \mu \mathrm{m}$ pre-filter and the $20 \mu \mathrm{m}$ bursting filter. Then, following this methodology, we obtained histograms with relatively low background and distinct peaks.

To confirm ploidy differences between the selected Citrus genotypes, we performed comparative measurements of nuclei isolated from leaf tissue of two different clementine genotypes. In both cases, only one dominant peak was observed with the diploid genotype (IVIA-039) showing the peak at a fluorescence value twice as big as that of the haploid genotype (IVIA-638) (Figure 2). Subsequently, we analyzed the ploidy level of mature pollen grains of 45 diploid, 7 triploid, and 6 tetraploid genotypes (Table 1). Forty-three of the 45 diploids showed histograms with two peaks (Figure 3B), corresponding to the $1 \mathrm{C}$ peak of the vegetative nuclei $(\mathrm{V})$ and the $2 \mathrm{C}$ peak of the generative nuclei as it is typical for species with binucleate pollen (Van Tuyl et al., 1989; Bino et al., 1990; Kron and Husband, 2012). However, exceptions 

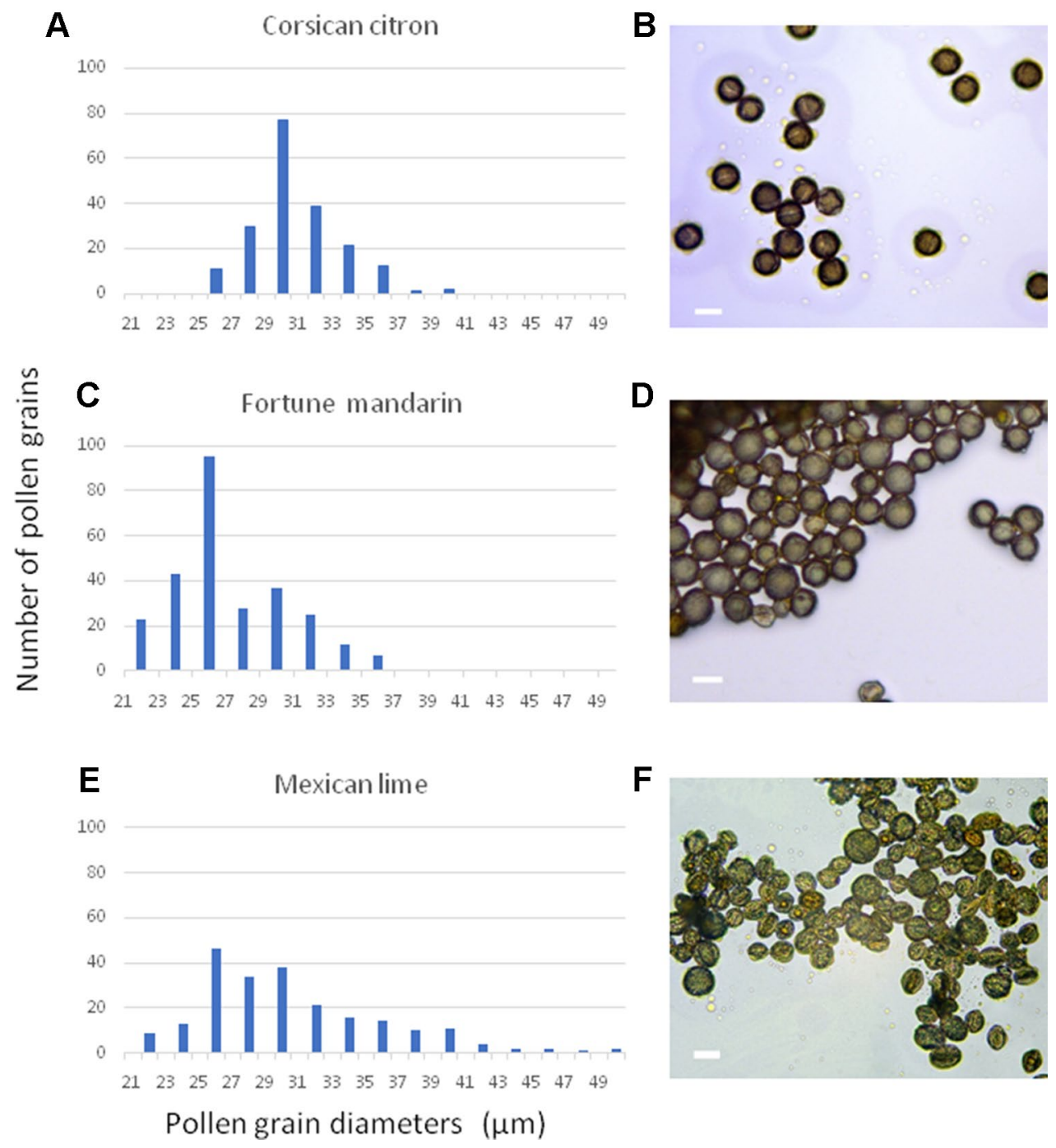

FIGURE 1 | Distribution of representative frequencies and images showing the heterogeneity of pollen diameters in three citrus genotypes: (A, B) "Corsican" citron, (C, D) "Fortune"mandarin, (E, F) "Mexican" lime. Scale bars, 30um.

were observed for "CSO" tangor and "Mexican" lime. Pollen from the "CSO" tangor produced a histogram with an additional third peak (Figure 3A-C). The fluorescence values of the first two nuclei populations coincide with the values obtained for the other diploid genotype analyzed (1V, 1G), whereas the third peak (1VG) displayed a higher fluorescence intensity than the other two peaks (Figures 3B, C). To identify the origin of this third peak, we sorted nuclei corresponding to the three individual peaks separately and evaluated them microscopically. Nuclei from the populations $1 \mathrm{~V}$ and $1 \mathrm{G}$ revealed different chromatin structures. While the population with the lower fluorescence intensity corresponding to the vegetative nuclei $(1 \mathrm{~V})$ revealed a relaxed chromatin condensation, the generative nuclei (1G) showed a condensed chromatin structure (Figure 3C). Interestingly, the third peak (1VG) reflects two nuclei attached to each other, one with a relaxed structure and one with a compact structure (Figure 3C).
On the other hand, pollen nuclei from "Mexican" lime showed five populations (Figure 3D, E). Beside $1 \mathrm{~V}$ and $1 \mathrm{G}$ populations, which were also present in the other diploid genotypes analyzed; we found two additional populations with twice the fluorescence value of $1 \mathrm{~V}$ and $1 \mathrm{G}$ nuclei populations which were named $2 \mathrm{~V}$ and $2 \mathrm{G}$, respectively $(2 \mathrm{~V} / 1 \mathrm{~V}=1.98 ; 2 \mathrm{G} / 1 \mathrm{G}=1.98)$; and a fifth small peak with twice the fluorescence of the $2 \mathrm{G}$ peak, named $4 \mathrm{G}$, with a correlation in the DNA content of the $4 \mathrm{G}$ and $2 \mathrm{G}$ populations $(4 \mathrm{G} / 2 \mathrm{G}=1.94)$. The fluorescence ratios between $2 \mathrm{~V} / 1 \mathrm{~V}$ and $2 \mathrm{G} / 1 \mathrm{G}$ indicate that $2 \mathrm{~V}$ and $2 \mathrm{G}$ peaks potentially contain unreduced gametes, whereas the $4 \mathrm{G}$ peak might correspond to a population of tetraploid nuclei that could be originated as a consequence of doubled-unreduced gametes. However, due to a low number of viable pollen grains in "Mexican" lime (Pons et al., 2011; Rouiss et al., 2018), the number of nuclei of the corresponding ploidy levels is relatively low and the resulting peaks not very pronounced. 


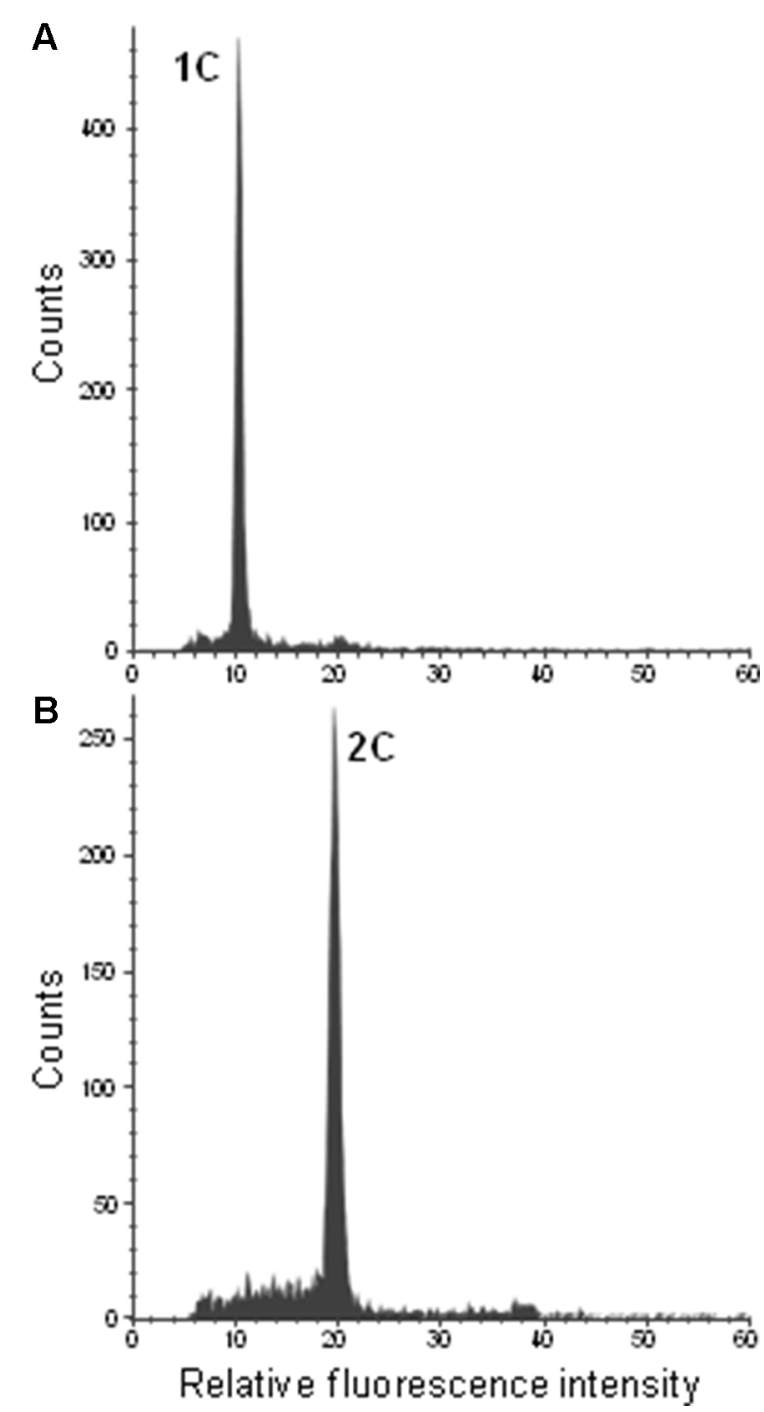

FIGURE 2 | Flow cytometric histograms of DAPI-stained leaf nuclei of the haploid control plant IVIA-638 (A) and the diploid control plant IVIA-039 (B) of clementine.

The tetraploid genotypes showed two populations of nuclei with fluorescence values twice as high as that of the populations of the $1 \mathrm{~V}$ and $1 \mathrm{G}$ nuclei of diploid genotypes (Figure 4). Nuclei of pollen grains of triploid genotypes could not be isolated (data not shown).

\section{FACS, WGA, and Genotyping of Single Pollen Nuclei}

In order to determine the genotype underlying the three different populations of pollen nuclei found in "CSO" tangor, FACS-based isolation of single nuclei coupled with wholegenome amplification was performed. A total of 72 nuclei were isolated, 24 nuclei from each of the three fluorescence peaks (1V, 1G and 1VG, Figure 3C), along with 20 nuclei sorted into the same well as positive control and leaf DNA. To confirm the successful sorting of the nuclei in single microwells and to identify their genetic origin, WGA products were analyzed with five SSR and three SNP markers heterozygous for "CSO" tangor (Table 3) located in eight different linkage groups (LGs) of th e clementine genetic map (Ollitrault et al., 2012). From the 72 nuclei, 63 displayed at least $50 \%$ of positive PCR reactions (87.5\%). Out of $576 \mathrm{PCR}$ reactions for all marker combinations, 487 were positive $(84.5 \%)$.

The marker call rates were $68.2 \%$ for the $1 \mathrm{~V}$ nuclei population, $91.7 \%$ for the $1 \mathrm{G}$ nuclei population and $95.8 \%$ for the $1 \mathrm{VG}$ population (Table 3 ). These results could be related with the increasing number of copies in each nuclei population. The marker analysis displayed heterozygosity for the leaf and pollen positive controls, as expected (Table 3 ). In contrast, only one allele was observed with all SSR and SNP markers for the $1 \mathrm{~V}$, $1 \mathrm{G}$, and $1 \mathrm{VG}$ nuclei populations. Therefore, we confirmed that the three nuclei populations recovered from pollen grains of the diploid "CSO" tangor are based on a single allele of the same origin each. In addition, the fact that the nuclei population with the highest fluorescence peak (1VG) is homozygous reflects that this population is composed of two attached nuclei $(1 \mathrm{~V}+1 \mathrm{G})$ derived from the same pollen grain.

Taken together the results obtained with molecular markers for "CSO" tangor and the histogram obtained after ploidy level analysis of mature pollen grains of "Mexican" lime, we can consider that the peaks $1 \mathrm{~V}$ and $1 \mathrm{G}$ in "Mexican" lime correspond to vegetative and generative nuclei, whereas $2 \mathrm{~V}$ and $2 \mathrm{G}$ peaks correspond to unreduced gametes.

We tested the genotyping of WGA-diploid nuclei as an approach to identify unreduced gametes by isolating and amplifying individualized nuclei from leaves of several genotypes, along with DNA from leaves and 20 leaf nuclei mixed from each genotype. Out of the 40 amplified nuclei, 24 produced positive PCR amplifications for at least $50 \%$ of the analyzed markers (62.5\%). The amplification ratios were $70 \%$ for "Carrizo" citrange, $90 \%$ for "Mexican" lime and $60 \%$ for "Eureka" lemon and "Moncada" mandarin. For these leaf nuclei, the ratios of the allele signals for all marker-genotype combinations are scattered in the plot, without forming a clear heterozygous group, as expected, and even showing homozygous amplifications. For example, DNA from leaves and leaf nuclei positive control of "Mexican" lime genotyped with the CHI-M598 SNP marker, resulted in heterozygous call rates (CG alleles), as expected. Furthermore, we used DNA from homozygous leaf controls, producing homozygosity for each allele, CC and GG signals. However, leaf nuclei amplifications displayed no defined heterozygous clusters and even some amplifications are grouped together with the homozygous controls (Figure 5). These results show that the WGA kit in at least some cases only amplifies a single allele of the two present alleles or the allele amplification is not balanced (Figure 5). With these results, the WGA of diploid nuclei of unreduced gametes of "Mexican" cannot be used for genotyping and to identify the mechanism underlying the formation of $2 \mathrm{n}$ pollen gametes. 

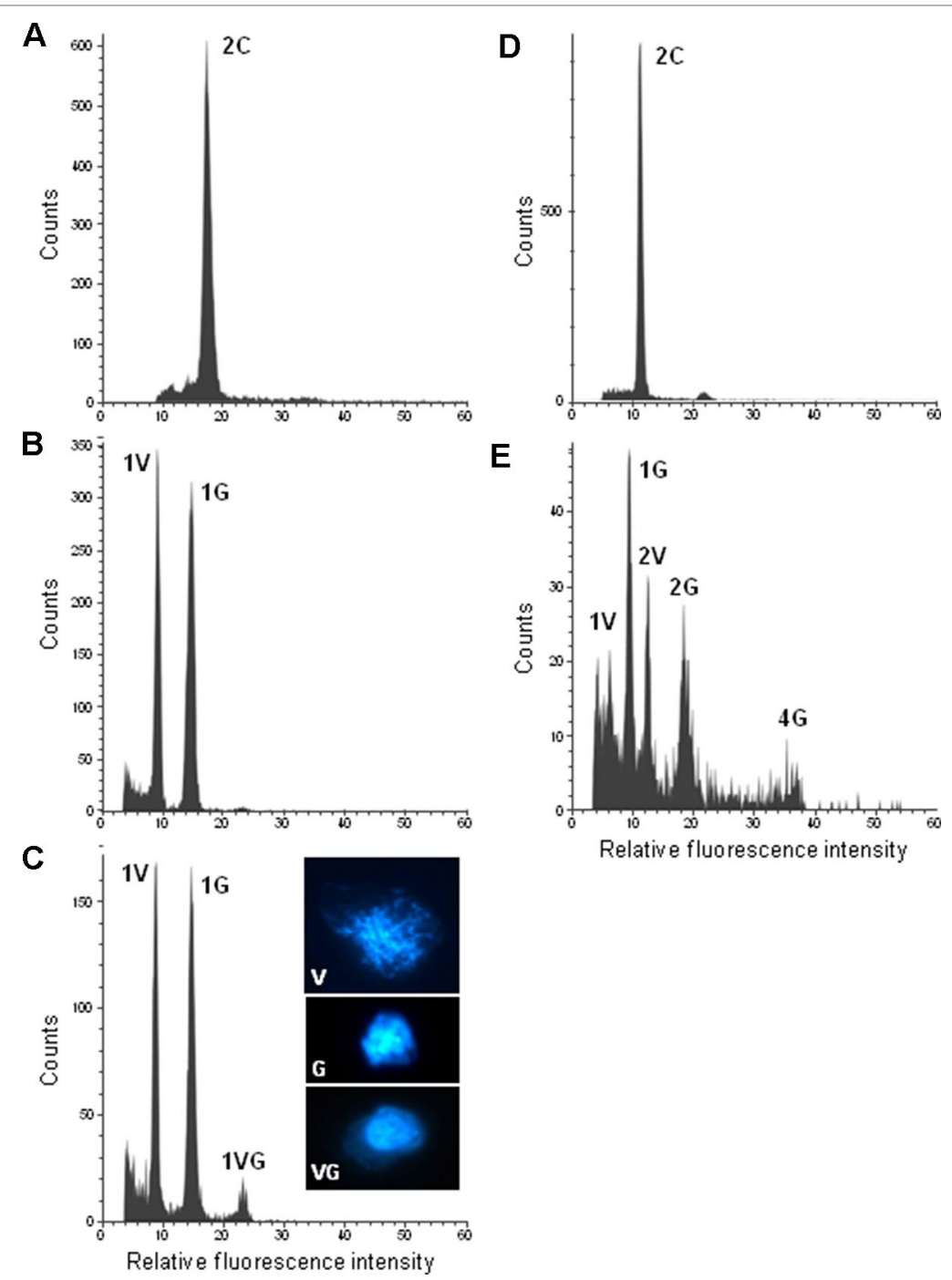

FIGURE 3 | Flow cytometric measurements of DAPI-stained leaf and pollen nuclei of diploid citrus genotypes: (A) "CSO" tangor leaf. (B) "Moncada" mandarin pollen. (C) "CSO" tangor pollen. (D) "Mexican" lime leaf. (E) "Mexican" lime pollen. Inserts in c show examples of flow sorted pollen nuclei of the corresponding histogram peaks of "CSO" tangor. V, G and VG represent vegetative, generative and vegetative plus generative pollen nuclei, respectively. Please note that the histograms of "CSO" tangor and "Mexican" lime were recorded on different days with different cytometer settings resulting in a variation in the peak positions when both genotypes are compared with each other.

\section{DISCUSSION}

\section{Flow Cytometry Is a Simple and Efficient Method to Determine the Ploidy Level of Citrus Pollen Grains}

The applications of flow cytometry has increased considerably since its inception (Doležel et al., 2007; Orbović et al., 2008; Adan et al., 2017; Bourge et al., 2018; Hoang et al., 2019). This method has become a reliable and fast tool in plant biology to determine the nuclear DNA content (Kron and Husband, 2012; Hoang et al., 2019) as well as ploidy levels (Eeckhaut et al., 2005; Ochatt, 2008; Bourge et al., 2018). In citrus, flow cytometry has been mainly used to determine the genome size and the ploidy level of somatic tissue in many breeding programs (Ollitrault and Michaux-Ferrière, 1992; Seker et al., 2003; Guo et al., 2004; Orbović et al., 2008; Aleza et al., 2009a; Dutt et al., 2010; Cuenca et al., 2011; Kamiri et al., 2011; Aleza et al., 2012a; Aleza et al., 2012b; Navarro et al., 2015; Rouiss et al., 2017a; Rouiss et al., 2017b; Kamiri et al., 2018).

In recent years, flow cytometry has also been used to study the DNA content of pollen nuclei in a large number of plant genera, which opens up new opportunities to study the meiotic processes, such as sexual polyploidization (Dewitte et al., 2009; Kron and Husband, 2015; Sora et al., 2016; Kreiner et al., 2017;), and demonstrating that many angiosperms are capable of producing 2n gametes (Van Tuyl et al., 1989; Pan et al., 2004; Kron and Husband, 2012; Chung et al., 2013). In this paper, we apply for the first time flow cytometry to study pollen grain populations in 

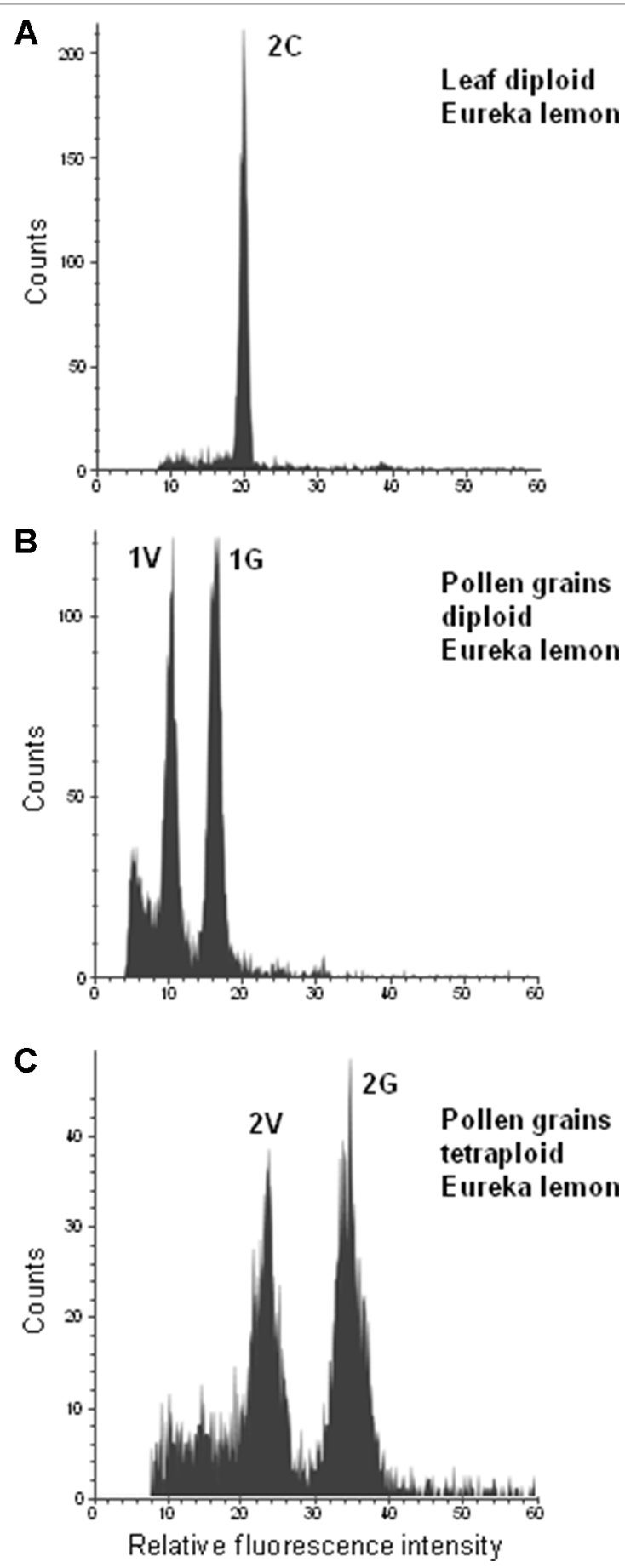

FIGURE 4 | Flow cytometric measurements of leaf and pollen nuclei of "Eureka" lemon. (A) Diploid "Eureka" lemon leaf, (B) Pollen of Diploid "Eureka" lemon. (C) Pollen of tetraploid "Eureka" lemon.

several species of the genus Citrus. Our study confirms that flow cytometry as a simple and cost-effective methodology to determine the ploidy level of citrus pollen grains. Quality histograms were obtained with DAPI-stained pollen nuclei, as reported for other species (Van Tuyl et al., 1989; Pan et al., 2004; Doležel et al., 2007; Dewitte et al., 2009; Kron and Husband, 2012).
The DNA content of haploid leaf nuclei is expected to be similar to that of the vegetative pollen nuclei, as their ploidy level is $\mathrm{x}$ (in the case of Citrus $\mathrm{x}=9$ ), while the DNA content in diploid nuclei from leaf is expected to be similar to that of the generative pollen nuclei, as their DNA content is $2 \mathrm{C}$. However, we have observed slightly lower fluorescence for the generative pollen nuclei in comparison with leaf nuclei. These differences have also been reported for other species (Van Tuyl et al., 1989; Bino et al., 1990; Dewitte et al., 2009; Kron and Husband, 2012). The reason behind could be structural differences between the generative and leaf nuclei (Bennett and Leitch, 2005) and fluorescence inhibition that operates differently on leaf and the pollen nuclei (Price et al., 2000).

We confirmed by microscopy and flow cytometry that mature pollen grains of citrus are binucleated. Histograms of the analyzed pollen grains from diploid donors revealed the clear presence of two populations with different fluorescence intensities, which agrees with what was found for pollen grains of other diploid angiosperm species (Van Tuyl et al., 1989; Bino et al., 1990; Pan et al., 2004; Dewitte et al., 2009; Kron and Husband, 2012). The first population contained vegetative nuclei, with half of the DNA content of leaf nuclei whereas the second population composed of generative nuclei has almost the same DNA content as the leaf tissue. This indicates that the generative nucleus is in the post replication stage of the cell division (G2) (Van Tuyl et al., 1989; Bino et al., 1990; Dewitte et al., 2009; Kron and Husband, 2012; Kron and Husband, 2015). Afterwards, the generative nuclei performs a further mitotic division to produce twin sperm cells responsible for the double fecundation (Berger and Twell, 2011). Citrus pollen contained nuclei having structural differences. The vegetative nucleus is large and less condensed, while the generative nucleus is more condensed. These differences have also been observed in other species (Dewitte et al., 2009; Alonso Peña, 2011; Kron and Husband, 2015). Only two exceptions were found in the analyzed histograms of the diploid genotypes "CSO" tangor and "Mexican" lime, in which beside $1 \mathrm{~V}$ and $1 \mathrm{G}$ peaks additional peaks were found.

In "CSO" tangor, we observed an additional peak named $1 \mathrm{VG}$, (Figure 3C). The fluorescence value of this peak suggests that the vegetative and generative nuclei of the same cell remained attached to each other after the opening of the pollen using the bursting-isolation method. In addition, we confirmed with SSR and SNPs markers that the each of the three nuclei populations has an identical genetic origin. On the other hand, Rouiss et al. (2017a) identified the presence of unreduced pollen from the diploid genotype "CSO" by analyzing tetraploid progenies obtained with a tetraploid female parent. However, we did not find any peak corresponding to unreduced pollen. In this context, in addition to genetic factors, the generation of unreduced gametes is also influenced by environmental factors (Souza et al., 2004; d'Erfurth et al., 2009; Dewitte et al., 2009; Aleza et al., 2010; Mason et al., 2011; De Storme et al., 2012; De Storme and Geelen, 2013; Sora et al., 2016; Wang et al., 2017), which might not be favoring their production during the season covered by the present study. In fact, tetraploid progenies from "CSO" were only obtained during the season in which Rouiss et al. (2017a) performed their study ( $H$. Rouiss, personal communication). 
TABLE 3 | Results by linkage group (LG) and molecular marker of the diploid genotype "CSO" for populations of vegetative nuclei $1 \mathrm{~V}$, generative nuclei $1 \mathrm{G}$ and attached nuclei 1VG.

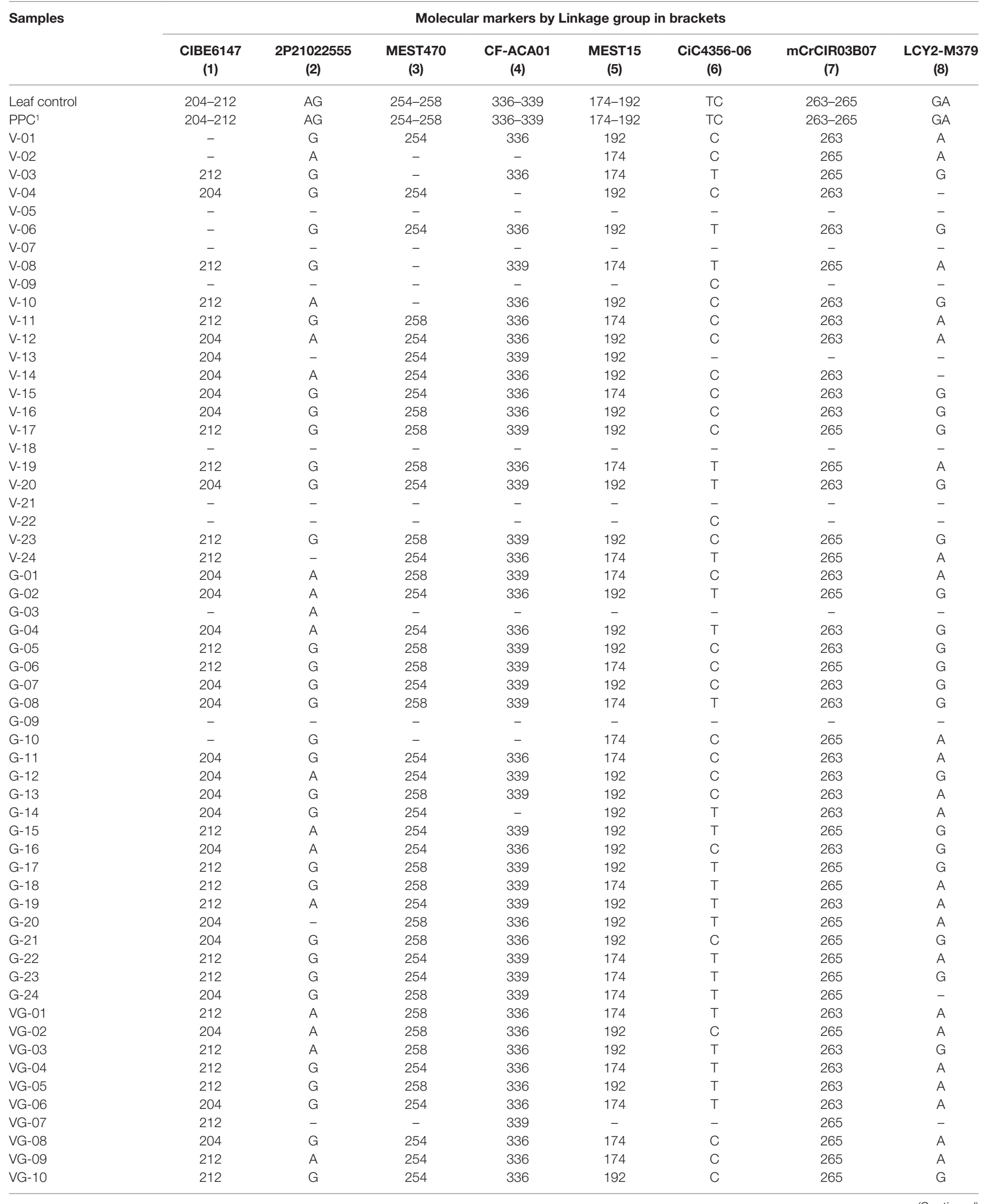


TABLE 3 | Continued

Samples

Molecular markers by Linkage group in brackets

\begin{tabular}{|c|c|c|c|c|c|c|c|c|}
\hline & $\begin{array}{c}\text { CIBE6147 } \\
\text { (1) }\end{array}$ & $\begin{array}{c}\text { 2P21022555 } \\
\text { (2) }\end{array}$ & $\begin{array}{l}\text { MEST470 } \\
\text { (3) }\end{array}$ & $\begin{array}{c}\text { CF-ACA01 } \\
\text { (4) }\end{array}$ & $\begin{array}{l}\text { MEST15 } \\
\text { (5) }\end{array}$ & $\begin{array}{c}\mathrm{CiC} 4356-06 \\
(6)\end{array}$ & $\begin{array}{c}\mathrm{mCrCIR03B07} \\
\text { (7) }\end{array}$ & $\begin{array}{c}\text { LCY2-M379 } \\
\text { (8) }\end{array}$ \\
\hline VG-11 & 212 & $A$ & 254 & 336 & 192 & $\mathrm{C}$ & 265 & A \\
\hline VG-12 & 212 & $G$ & 254 & 336 & 174 & C & 265 & $G$ \\
\hline VG-13 & 212 & $G$ & 254 & 336 & 174 & $\mathrm{~T}$ & 265 & $A$ \\
\hline VG-14 & 212 & $G$ & 254 & 336 & 174 & C & 263 & $G$ \\
\hline VG-15 & 204 & A & 258 & 336 & 174 & $\mathrm{C}$ & 265 & $G$ \\
\hline VG-16 & 204 & $G$ & 258 & 336 & 192 & $\mathrm{C}$ & 265 & A \\
\hline VG-17 & 212 & $G$ & 258 & 336 & - & $\mathrm{T}$ & - & $G$ \\
\hline VG-18 & 212 & $G$ & 254 & 336 & 192 & $\mathrm{~T}$ & 263 & $G$ \\
\hline VG-19 & 212 & $G$ & 258 & 336 & 192 & $\mathrm{C}$ & 265 & $A$ \\
\hline VG-20 & 204 & $G$ & 254 & 336 & 174 & C & 263 & A \\
\hline VG-21 & 212 & $G$ & 258 & 339 & 192 & C & 263 & A \\
\hline VG-22 & 212 & $G$ & 254 & 336 & 192 & $\mathrm{~T}$ & 263 & $G$ \\
\hline VG-23 & 212 & $G$ & 258 & 339 & 192 & $\mathrm{~T}$ & 263 & $G$ \\
\hline VG-24 & 212 & A & 254 & 336 & 192 & C & 265 & $A$ \\
\hline
\end{tabular}

${ }^{1}$ PPC, Pollen positive control.

$V$ samples correspond to nuclei isolated from the $1 \mathrm{~V}$ fluorescence peak, G from the $1 \mathrm{G}$ fluorescence peak and VG from the $1 \mathrm{VG}$ fluorescence peak.

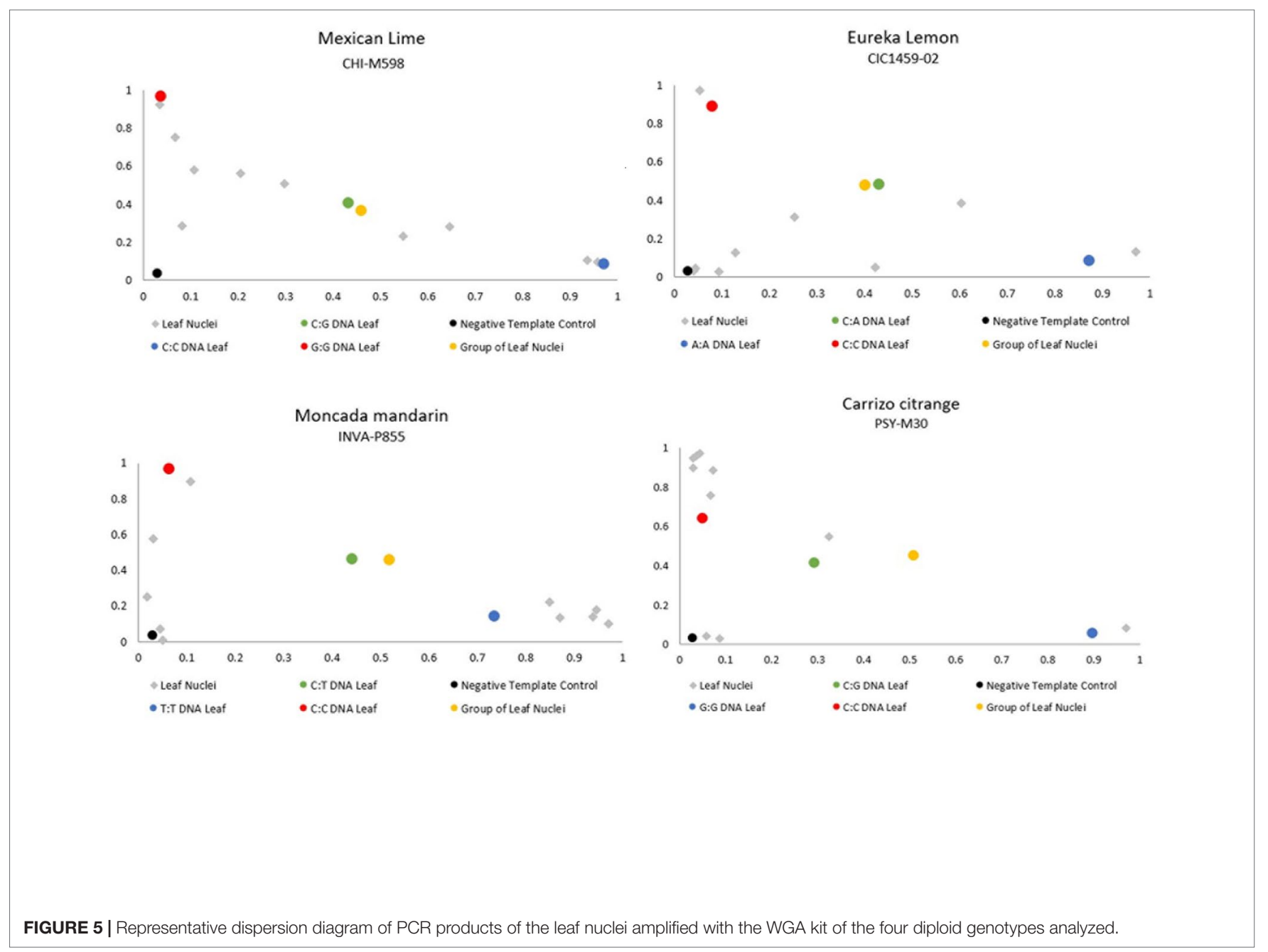


Nevertheless, our methodology could be applied to further studies focused on how temperature stress or environmental conditions could influence the formation of $2 \mathrm{n}$ gametes in citrus.

Unreduced pollen grains were observed in the diploid "Mexican" lime. To our knowledge, this is the first report on the observation of this type of pollen population by flow cytometry in Citrus. The "Mexican" lime pollen showed $2 \mathrm{~V}$ and $2 \mathrm{G}$ nuclei populations, with similar fluorescence intensit as the vegetative and generative pollen nuclei of tetraploid genotypes. The presence of pollen nuclei with a duplicated DNA content (2G) in comparison to leaf nuclei (2C) was observed for other plant genera before (Van Tuyl et al., 1989; Bino et al., 1990; Dewitte et al., 2009). In addition, a 4G nuclei population was observed with a double DNA content of the $2 \mathrm{G}$ population which could be due to the formation of doubledunreduced gametes. This phenomenon is unusual although the formation of tetraploid pollen due to the lack of post-meiotic cytokinesis in all microspore mother cells has been described in alfalfa (McCoy and Smith, 1983; Pfeiffer and Bingham, 1983; Tavoletti et al., 2000). Doubled-unreduced gametes have been observed in interspecific strawberry hybrids (Bringhurst and Gill, 1970). We also observed large pollen grains in this genotype (Figure 1F). The presence of enlarged pollen grains is generally associated with the formation of unreduced gametes (Jones et al., 2007; Honsho et al., 2016). The "Mexican" lime is a interspecific hybrid between $C$. micrantha $\times$ C. medica (Nicolosi et al., 2000; Garcia-Lor et al., 2013b; Curk et al., 2016). It is known that interspecific hybrids of other plant genera show a tendency towards the formation of unreduced gametes (Van Tuyl et al., 1989; Ramanna et al., 2003; Mason et al., 2011; Chung et al., 2013; Martin et al., 2019). In addition, Curk et al. (2016) proposed that C. latifolia ("Tahiti" lime like accessions) resulted from the fertilization of a haploid lemon ovule by a diploid gamete of a diploid "Mexican" like lime. These observations support the hyphothesis that "Mexican" lime produce unreduced pollen gametes.

In contrast to all diploid and tetraploid genotypes, the results obtained from the analysis of the triploid genotypes showed no clear peaks in the histograms. In general, citrus triploid hybrids do not produce seeds or induce seeds in other genotypes by cross-pollination since they have very low male and female fertility (Aleza et al., 2010; Aleza et al., 2012a; Phillips et al., 2016). Odd-numbered polyploids oftenhave pollen of high rates of infertility or aneuploidy, as reported for other species (e.g. Aeschynanthus spp., Alstroemeria spp., Crocus spp., Lilium spp.; Rounsaville et al., 2011; Kron and Husband, 2012; Phillips et al., 2016). The absence of clear peaks in the histograms has been demonstrated to be due to pollen infertility.

Our flow cytometry analysis of pollen from tetraploid genotypes revealed the presence of two populations, i.e., vegetative and generative pollen nuclei, both showing twice the fluorescence than their counterpart nuclei in the diploid genotypes. Although cases of unreduced pollen have been reported in diploid citrus genotypes (Honsho et al., 2016; Rouiss et al., 2017a), little is known regarding tetraploid genotypes. In studies of progenies from controlled $2 \mathrm{X} \times 4 \mathrm{X}$ hybridizations, where the female parent is self-incompatible, double reduced haploid pollen gametes were observed, resulting in diploid plants (Aleza et al., 2012a). Kamiri et al. (2009) also reported the production of haploid gametes from citrus allotetraploid somatic hybrids. Koutecký et al. (2011) observed one pentaploid hybrid between diploid Centaurea pseudofirgia and tetraploid C. jacea, arising from a reduced diploid ovule and a tetraploid unreduced pollen grain. These studies showed that tetraploid genotypes can produce pollen grains with different ploidy levels than the expected, and these variants are difficult to identify by flow cytometry.

\section{FACS Coupled With WGA Is an Effective Tool for the Genotyping of Individualized Pollen Nuclei}

We demonstrate that the FACS strategy can be applied to isolate individual nuclei of citrus, allowing their classification and further amplification and genotyping. The use of WGA for individualized nuclei combined with genotyping provides the opportunity to use a large number of molecular markers (Dreissig et al., 2015; Gawad et al., 2016; Dreissig et al., 2017).

The results obtained with the molecular markers allowed us to conclude that the $1 \mathrm{~V}, 1 \mathrm{G}$, and $1 \mathrm{VG}$ nuclei populations observed in the "CSO" genotype correspond to reduced and not to unreduced pollen. These findings are of importance for the interpretation of the histograms. We can affirm that, in citrus, the presence of a second peak in pollen from diploid and tetraploid genotypes does not imply their correspondence with $2 \mathrm{n}$ pollen, and are in agreement with binuclated citrus pollen grains. To our knowledge, this is the first report in citrus demonstrating that vegetative and generative nuclei have the same genetic configuration based on molecular markers as expected. In this context, vegetative and generative nuclei populations have been identified in different woody and herbaceous species (Van Tuyl et al., 1989; Bino et al., 1990; Dewitte et al., 2009; Kron and Husband, 2012; Kreiner et al., 2017), but their genetic constitution has not been demonstrated.

The use of the WGA method and further genotyping with SSR and SNPs markers shows to be reliable for the genotyping of haploid nuclei isolated from mature pollen grains, offering new approaches to increase our knowledge about citrus genetics. However, the amplifications of diploid leaf nuclei did not show the expected results. WGA of those nuclei and their genotyping with heterozygous markers resulted in unbalanced amplifications, losing the 1:1 expected ratio and biased towards one of the two alleles. This allelic imbalance has been previously observed in single-cell genomic sequencing studies also, which is attributed to the bias in the whole genome amplification that occurs in the initial reaction, which is exaggerated by further reactions (de Bourcy et al., 2014; Gawad et al., 2016; Yuan et al., 2018).

\section{CONCLUSIONS}

In this paper, we have demonstrated that flow cytometry is an efficient tool for the analysis of pollen grain nuclei 
populations in several citrus species. In addition, we report for the first time, the generation of unreduced pollen from the interspecific diploid "Mexican" lime. This methodology opens up new applications in citrus research studies, such as the determination if unreduced pollen frequency in breeding parents and the analysis of environmental conditions (e.g. temperature) on the frequency of the unreduced pollen. Sorted nuclei can be used for subsequent WGA for further genetic studies. The whole genome amplified samples can be used to perform studies related to allele segregation, genetic mapping and meiotic crossovers, without the interference that can be encountered when analyzing the derived progenies. However, WGA from diploid leaf nuclei was generally biased towards one allele, thus hampering the genetic analysis of unreduced pollen and of normal diploid pollen arising from tetraploid parents.

Genotyping of the whole genome amplified DNA derived from single pollen nuclei with SSR and SNP molecular markers resulted in a call rate comparable with those previously reported for several species. The obtained results allowed the genetic analysis of single pollen nuclei arising from diploid parents. Altogether, the methodology presented here represents a very useful tool for facilitating research focused on assessing the genetic origin, evolution, and reproductive biology of citrus populations.

\section{REFERENCES}

Adan, A., Alizada, G., Kiraz, Y., Baran, Y., and Nalbant, A. (2017). Flow cytometry: basic principles and applications. Crit. Rev. Biotechnol. 37, 163-176. doi: 10.3109/07388551.2015.1128876

Aleza, P., Cuenca, J., Juárez, J., Navarro, L., and Ollitrault, P. (2016). Inheritance in doubled-diploid clementine and comparative study with SDR unreduced gametes of diploid clementine. Plant Cell Rep. 35, 1573-1586. doi: 10.1007/ s00299-016-1972-4

Aleza, P., Juárez, J., Cuenca, J., Ollitrault, P., and Navarro, L. (2010). Recovery of citrus triploid hybrids by embryo rescue and flow cytometry from $2 \mathrm{x} \times 2 \mathrm{x}$ sexual hybridisation and its application to extensive breeding programs. Plant Cell Rep. 29, 1023-1034. doi: 10.1007/s00299-010-0888-7

Aleza, P., Juárez, J., Cuenca, J., Ollitrault, P., and Navarro, L. (2012a). Extensive citrus triploid hybrid production by $2 \mathrm{x} \times 4 \mathrm{x}$ sexual hybridizations and parenteffect on the length of the juvenile phase. Plant Cell Rep. 31, 1723-1735. doi: 10.1007/s00299-012-1286-0

Aleza, P., Juárez, J., Hernández, M., Ollitrault, P., and Navarro, L. (2012b). Implementation of extensive citrus triploid breeding programs based on $4 \mathrm{x} \times$ 2x sexual hybridisations. Tree Genet. Genomes 8, 1293-1306. doi: 10.1007/ s11295-012-0515-6

Aleza, P., Juárez, J., Hernández, M., Pina, J. A., Ollitrault, P., and Navarro, L. (2009a). Recovery and characterization of a Citrus clementina Hort. ex Tan. "Clemenules" haploid plant selected to establish the reference whole Citrus genome sequence. BMC Plant Biol. 9, 110. doi: 10.1186/1471-2229-9-110

Aleza, P., Juárez, J., Ollitrault, P., and Navarro, L. (2009b). Production of tetraploid plants of non apomictic citrus genotypes. Plant Cell Rep. 28, 1837-1846. doi: 10.1007/s00299-009-0783-2

Alonso Peña, J. R. (2011). Manual de histología vegetal. Madrid, España: Mundi Prensa.

Bennett, M. D., and Leitch, I. J. (2005). "Genome Size Evolution in Plants" in The Evolution of the Genome, ed. T. R. Gregory (Elsevier), 89-162. doi:10.1016/ B978-012301463-4/50004-8

Berger, F., and Twell, D. (2011). Germline Specification and Function in Plants. Annu. Rev. Plant Biol. 62, 461-484. doi: 10.1146/annurev-arplant-042110-103824

\section{DATA AVAILABILITY}

All relevant data is contained within the manuscript.

\section{AUTHOR CONTRIBUTIONS}

MG and PA conceived the study and were in charge of the direction and planning. JF isolated pollen nuclei and conducted flow-sorting. SD performed whole genome amplification from single pollen nuclei. MG, JC, and PA genotyped pollen nuclei and analyzed the data. MG, JC, and PA took the lead writing the manuscript with input and review of SD, JF, and $\mathrm{AH}$. All authors read and approved the final version of this manuscript.

\section{FUNDING}

This work was supported by the project RTA2015-00069-0000 from the Ministry of "Economía y Competividad" and "Instituto Nacional de Investigación y Tecnología Agraria y Agroalimentaria" and the grant "Programa de Perfeccionamiento" resolution 1177/14 from Consejo Directivo of Instituto Nacional de Tecnología Agropecuaria (Argentina).

Bino, R. J., Tuyl, J. M. VAN, and De Vries, J. N. (1990). Flow cytometric determination of relative nuclear DNA contents in bicellulate and tricellulate pollen. Ann. Bot. 65, 3-8. doi: 10.1093/oxfordjournals.aob. a087904

Bourge, M., Brown, S. C., and Siljak-Yakovlev, S. (2018). Flow cytometry as tool in plant sciences, with emphasis on genome size and ploidy level assessment. Genet. Appl. 2, 1. doi: 10.31383/ga.vol2iss2pp1-12

Bringhurst, R. S., and Gill, T. (1970). Origin of Fragaria polyploids. II. Unreduced and doubled-unreduced gametes. Am. J. Bot. 57, 969-976. doi: 10.1002/j.15372197.1970.tb09896.x

Chung, M.-Y., Chung, J.-D., Ramanna, M., Van Tuyl, J. M., and Lim, K.-B. (2013). Production of polyploids and unreduced gametes in Lilium auratum $\times \mathrm{L}$. henryi Hybrid. Int. J. Biol. Sci. 9, 693-701. doi: 10.7150/ijbs.6427

Cuenca, J., Aleza, P., Juárez, J., García-Lor, A., Froelicher, Y., Navarro, L., et al. (2015a). Maximum-likelihood method identifies meiotic restitution mechanism from heterozygosity transmission of centromeric loci: application in citrus. Sci. Rep. 5, 9897. doi: 10.1038/srep09897

Cuenca, J., Aleza, P., Iborra, E., Vicent, A., Ollitrault, P., and Navarro, L. (2015b). Location of a chromosome region linked to Alternaria brown spot resistance from the evaluation of triploid mandarin populations. Acta Hortic. 1065, 415425. doi:10.17660/ActaHortic.2015.1065.51

Cuenca, J., Froelicher, Y., Aleza, P., Juárez, J., Navarro, L., and Ollitrault, P. (2011). Multilocus half-tetrad analysis and centromere mapping in citrus: evidence of SDR mechanism for $2 \mathrm{n}$ megagametophyte production and partial chiasma interference in mandarin cv "Fortune". Heredity 107, 462-470. doi: 10.1038/ hdy. 2011.33

Cuppen, E. (2007). Genotyping by Allele-Specific Amplification (KASPar). Cold Spring Harb. Protoc. 2007, pdb.prot4841. doi:10.1101/pdb.prot4841.

Curk, F., Ancillo, G., Ollitrault, F., Perrier, X., Jacquemoud-Collet, J.-P., Garcia-Lor, A., et al. (2015). Nuclear species-diagnostic SNP markers mined from 454 amplicon sequencing reveal admixture genomic structure of modern citrus varieties. PLoS One 10, e0125628. doi: 10.1371/journal.pone.0125628

Curk, F., Ollitrault, F., Garcia-Lor, A., Luro, F., Navarro, L., and Ollitrault, P. (2016). Phylogenetic origin of limes and lemons revealed by cytoplasmic and nuclear markers. Ann. Bot. 117, 565-583. doi: 10.1093/aob/mcw005 
d'Erfurth, I., Jolivet, S., Froger, N., Catrice, O., Novatchkova, M., and Mercier, R. (2009). Turning meiosis into mitosis. PLoS Biol. 7, e1000124. doi: 10.1371/ journal.pbio.1000124

de Bourcy, C. F. A., De Vlaminck, I., Kanbar, J. N., Wang, J., Gawad, C., and Quake, S. R. (2014). A quantitative comparison of single-cell whole genome amplification methods. PLoS One 9, e105585. doi: 10.1371/journal. pone. 0105585

De Storme, N., Copenhaver, G. P., and Geelen, D. (2012). Production of diploid male gametes in arabidopsis by cold-induced destabilization of postmeiotic radial microtubule arrays. Plant Physiol. 160, 1808-1826. doi: 10.1104/pp. 112.208611

De Storme, N., and Geelen, D. (2013). Sexual polyploidization in plants cytological mechanisms and molecular regulation. New Phytol. 198, 670-684. doi: $10.1111 / \mathrm{nph} .12184$

Dewitte, A., Eeckhaut, T., Van Huylenbroeck, J., and Van Bockstaele, E. (2009). Occurrence of viable unreduced pollen in a Begonia collection. Euphytica 168, 81-94. doi: 10.1007/s10681-009-9891-x

Doležel, J., Greilhuber, J., and Suda, J. (2007). Flow cytometry with plant cells: analysis of genes, chromosomes and genomes. Wiley-VCH. doi: 10.1002/ 9783527610921

Dreissig, S., Fuchs, J., Cápal, P., Kettles, N., Byrne, E., and Houben, A. (2015). Measuring meiotic crossovers via multi-locus genotyping of single pollen grains in barley. PLoS One 10, e0137677. doi: 10.1371/journal.pone.0137677

Dreissig, S., Fuchs, J., Himmelbach, A., Mascher, M., and Houben, A. (2017). Sequencing of single pollen nuclei reveals meiotic recombination events at megabase resolution and circumvents segregation distortion caused by postmeiotic processes. Front. Plant Sci. 8, 1620. doi: 10.3389/fpls.2017.01620

Dutt, M., Vasconcellos, M., Song, K. J., Gmitter, F. G., and Grosser, J. W. (2010). In vitro production of autotetraploid Ponkan mandarin (Citrus reticulata Blanco) using cell suspension cultures. Euphytica 173, 235-242. doi: 10.1007/ s10681-009-0098-y

Eeckhaut, T., Leus, L., and Van Huylenbroeck, J. (2005). Exploitation of flow cytometry for plant breeding. Acta Physiol. Plant. 27, 743-750. doi: 10.1007/ s11738-005-0079-2

Galbraith, D. W., Harkins, K. R., Maddox, J. M., Ayres, N. M., Sharma, D. P., and Firoozabady, E. (1983). Rapid flow cytometric analysis of the cell cycle in intact plant tissues. Science (80-.) 220, 1049-1051. doi: 10.1126/science.220.4601.1049

Garcia-Lor, A., Ancillo, G., Navarro, L., and Ollitrault, P. (2013a). Citrus (Rutaceae) SNP markers based on competitive allele-specific PCR; Transferability across the aurantioideae subfamily. Appl. Plant Sci. 1, 1200406. doi: 10.3732/ apps.1200406

Garcia-Lor, A., Curk, F., Snoussi-Trifa, H., Morillon, R., Ancillo, G., Luro, F., et al. (2013b). A nuclear phylogenetic analysis: SNPs, indels and SSRs deliver new insights into the relationships in the 'true citrus fruit trees' group (Citrinae, Rutaceae) and the origin of cultivated species. Ann. Bot. 111, 1-19. doi: $10.1093 / \mathrm{aob} / \mathrm{mcs} 227$

García-Lor, A., Luro, F., Navarro, L., and Ollitrault, P. (2012). Comparative use of InDel and SSR markers in deciphering the interspecific structure of cultivated citrus genetic diversity: a perspective for genetic association studies. Mol. Genet. Genomics 287, 77-94. doi: 10.1007/s00438-011-0658-4

Gawad, C., Koh, W., and Quake, S. R. (2016). Single-cell genome sequencing: current state of the science. Nat. Rev. Genet. 17, 175-188. doi: 10.1038/ nrg.2015.16

Gu, C., Liu, Q.-Z., Yang, Y.-N., Zhang, S.-J., Khan, M. A., Wu, J., et al. (2013). Inheritance of hetero-diploid pollen S-haplotype in self-compatible tetraploid Chinese cherry (Prunus pseudocerasus Lindl). PLoS One 8, e61219. doi: 10.1371/journal.pone.0061219

Guo, W. W., Prasad, D., Serrano, P., Gmitter, F., and Grosser, J. W. (2004). Citrus somatic hybridization with potential for direct tetraploid scion cultivar development. J. Hortic. Sci. Biotechnol. 79, 400-405. doi: 10.1080/14620316.2004. 11511780

Hoang, P. T. N., Schubert, V., Meister, A., Fuchs, J., and Schubert, I. (2019). Variation in genome size, cell and nucleus volume, chromosome number and rDNA loci among duckweeds. Sci. Rep. 9, 3234. doi: 10.1038/ s41598-019-39332-w

Honsho, C., Sakata, A., Tanaka, H., Ishimura, S., and Tetsumura, T. (2016). Singlepollen genotyping to estimate mode of unreduced pollen formation in Citrus tamurana cv. Nishiuchi Konatsu. Plant Reprod. 29, 189-197. doi: 10.1007/ s00497-016-0277-7

Hou, Y., Wu, K., Shi, X., Li, F., Song, L., Wu, H., et al. (2015). Comparison of variations detection between whole-genome amplification methods used in single-cell resequencing. Gigascience 4, 37. doi:10.1186/s13742-015-0068-3.

Isagi, Y., and Suyama, Y. (2010). Single-pollen genotyping. Eds. Y. Isagi and Y. Suyama (Tokyo, Japan: Springer Science \& Business Media). Available at: https://books.google.es/books?id=U0meDUM0DQYC\&dq=Isagi,+Y.,+\%26+ Suyama\&lr $=\& h l=$ es\&source $=$ gbs_navlinks_s [Accessed November 30, 2018]. doi: 10.1007/978-4-431-53901-8

Jones, K. D., Reed, S. M., and Rinehart, T. A. (2007). Analysis of ploidy level and its effects and fertility in Hydrangea macrophylla. HortScience 42, 483-488. doi: 10.21273/HORTSCI.42.3.483

Kamiri, M., Srairi, I., Ollitrault, P., and Froelicher, Y. (2009). Origin of different ploidy levels of progeny from diploid $\times$ tetraploid somatic hybrid crosses in citrus. in International Conference on Polyploidy, Hybridization and Biodiversity, May 17 - 20, 2009, Saint-Malo, France, program and abstracts (Université de Rennes 1), 20230.

Kamiri, M., Stift, M., Costantino, G., Dambier, D., Kabbage, T., Ollitrault, P., et al. (2018). Preferential homologous chromosome pairing in a tetraploid intergeneric somatic hybrid (Citrus reticulata + Poncirus trifoliata) revealed by molecular marker inheritance. Front. Plant Sci. 9, 1-12. doi: 10.3389/fpls.2018.01557

Kamiri, M., Stift, M., Srairi, I., Costantino, G., Moussadik, A., Hmyene, A., et al. (2011). Evidence for non-disomic inheritance in a Citrus interspecific tetraploid somatic hybrid between C. reticulata, and C. limon using SSR markers and cytogenetic analysis. Plant Cell Rep. 30, 1415-1425. doi: 10.1007/ s00299-011-1050-x

Koutecký, P., Badurová, T., Štech, M., Košnar, J., and Karásek, J. (2011). Hybridization between diploid Centaurea pseudophrygia and tetraploid C. jacea (Asteraceae): the role of mixed pollination, unreduced gametes, and mentor effects. Biol. J. Linn. Soc. 104, 93-106. doi: 10.1111/j.1095-8312.2011.01707.x

Kreiner, J. M., Kron, P., and Husband, B. C. (2017). Frequency and maintenance of unreduced gametes in natural plant populations: associations with reproductive mode, life history and genome size. New Phytol. 214, 879-889. doi: $10.1111 /$ nph. 14423

Kron, P., and Husband, B. C. (2012). Using flow cytometry to estimate pollen DNA content: improved methodology and applications. Ann. Bot. 110, 1067-1078. doi: $10.1093 / \mathrm{aob} / \mathrm{mcs} 167$

Kron, P., and Husband, B. C. (2015). Distinguishing $2 \mathrm{~N}$ gamete nuclei from doublets in pollen using flow cytometry and pulse analysis. Cytom. Part A 87, 943-957. doi: $10.1002 /$ cyto.a.22696

Krug, C. (1943). Chromosome number in the subfamily Aurantioideae with special reference to the genus Citrus. Bot. Gaz. 104, 602-611. doi: 10.1086/335173

Lee, L. (1988). Citrus polyploidy - origins and potential for cultivar improvement. Aust. J. Agric. Res. 39, 735. doi: 10.1071/AR9880735

Martin, C., Viruel, M. A., Lora, J., and Hormaza, J. I. (2019). Polyploidy in fruit tree crops of the Genus Annona (Annonaceae). Front. Plant Sci. 10, 99. doi: 10.3389/fpls.2019.00099

Mase, N., Sawamura, Y., Yamamoto, T., Takada, N., Nishio, S., Saito, T., et al. (2014). Direct genotyping of single pollen grains of a self-compatible mutant of Japanese pear (Pyrus pyrifolia) revealed inheritance of a duplicated chromosomal segment containing a second S-haplotype. Euphytica 200, 297304. doi: 10.1007/s10681-014-1168-3

Mason, A. S., Nelson, M. N., Yan, G., and Cowling, W. A. (2011). Production of viable male unreduced gametes in Brassica interspecific hybrids is genotype specific and stimulated by cold temperatures. BMC Plant Biol. 11, 103. doi: 10.1186/1471-2229-11-103

Matsuki, Y., Isagi, Y., and Suyama, Y. (2007). The determination of multiple microsatellite genotypes and DNA sequences from a single pollen grain. Mol. Ecol. Notes 7, 194-198. doi: 10.1111/j.1471-8286.2006.01588.x

McCoy, T. J., and Smith, L. Y. (1983). Genetics, cytology, and crossing behavior of an alfalfa (Medicago sativa) mutant resulting in failure of the postmeiotic cytokinesis. Can. J. Genet. Cytol. 25, 390-397. doi: 10.1139/g83-060

Mishiba, K.-I., Ando, T., Mii, M., Watanabe, H., Kokubun, H., Hashimoto, G., et al. (2000). Nuclear DNA content as an index character discriminating taxa in the genus Petunia sensu Jussieu (Solanaceae). Ann. Bot. 85, 665-673. doi: 10.1006/ anbo. 2000.1122 
Navarro, L., Aleza, P., Cuenca, J., Juárez, J., Pina, J. A., Ortega, C., et al. (2015). The mandarin triploid breeding program in Spain. Acta Hortic. 1065, 389-395. doi:10.17660/ActaHortic.2015.1065.48

Navarro, L., Pina, J. A., Juárez, J., Ballester-Olmos, J. F., Arregui, J. M., Ortega, C., et al. (2002). The Citrus variety improvement program in Spain in the period 1975-2001. in Proceedings of the 15th Conference of the International Organization of Citrus Virologists, 306-316. Available at: https://escholarship. org/uc/item/42m9s93v [Accessed November 28, 2018].

Nicolosi, E., Deng, Z. N., Gentile, A., La Malfa, S., Continella, G., and Tribulato, E. (2000). Citrus phylogeny and genetic origin of important species as investigated by molecular markers. Theor. Appl. Genet. 100, 1155-1166. doi: 10.1007/ s001220051419

Ochatt, S. J. (2008). Flow cytometry in plant breeding. Cytom Part A 73A, 581-598. doi: 10.1002/cyto.a.20562

Ollitrault, F., Terol, J., Pina, J. A., Navarro, L., Talon, M., and Ollitrault, P. (2010). Development of SSR markers from Citrus clementina (Rutaceae) BAC end sequences and interspecific transferability in Citrus. Am. J. Bot. 97, e124-e129. doi: $10.3732 /$ ajb. 1000280

Ollitrault, P., Dambier, D., Luro, F., and Froelicher, Y. (2008). "Ploidy manipulation for breeding seedless triploid citrus," in Plant Breeding Reviews (Hoboken, NJ, USA: John Wiley \& Sons, Inc.), 323-352. doi: 10.1002/9780470380130.ch7

Ollitrault, P., and Michaux-Ferrière, N. (1992). Application of flow cytometry for citrus genetic and breeding. Int. Citrus Congr. 7, 20. Available at: http:// agritrop.cirad.fr/395790/ [Accessed February 13, 2019].

Ollitrault, P., Terol, J., Chen, C., Federici, C., Lotfy, S., Hippolyte, I., et al. (2012). A reference genetic map of C. clementina hort. ex Tan.; citrus evolution inferences from comparative mapping. BMC Genomics 13, 593. doi: 10.1186/ 1471-2164-13-593

Orbović, V., Ćalović, M., Viloria, Z., Nielsen, B., Gmitter, F. G., Castle, W. S., et al. (2008). Analysis of genetic variability in various tissue culture-derived lemon plant populations using RAPD and flow cytometry. Euphytica 161, 329-335. doi: 10.1007/s10681-007-9559-3

Pan, G., Zhou, Y., Fowke, L. C., and Wang, H. (2004). An efficient method for flow cytometric analysis of pollen and detection of $2 \mathrm{n}$ nuclei in Brassica napus pollen. Plant Cell Rep. 23, 196-202. doi: 10.1007/s00299-004-0830-y

Pfeiffer, T. W., and Bingham, E. T. (1983). Abnormal meiosis in alfalfa, Medicago sativa: cytology of $2 \mathrm{~N}$ egg and $4 \mathrm{~N}$ pollen formation. Can. J. Genet. Cytol. 25, 107-112. doi: 10.1139/g83-021

Phillips, W. D., Ranney, T. G., Touchell, D. H., and Eaker, T. A. (2016). Fertility and reproductive pathways of triploid flowering pears (Pyrus sp.). HortScience 51, 968-971. doi: 10.21273/HORTSCI.51.8.968

Pichot, C., and El Maâtaoui, M. (2000). Unreduced diploid nuclei in Cupressus dupreziana A. camus pollen. Theor. Appl. Genet. 101, 574-579. doi: 10.1007/ s001220051518

Pons, E., Navarro, A., Ollitrault, P., and Peña, L. (2011). Pollen competition as a reproductive isolation barrier represses transgene flow between compatible and co-flowering citrus genotypes. PLoS One 6, e25810. doi: 10.1371/journal. pone. 0025810

Price, H., Hodnett, G., and Johnston, J. S. (2000). Sunflower (Helianthus annuus) leaves contain compounds that reduce nuclear propidium iodide fluorescence. Ann. Bot. 86, 929-934. doi: 10.1006/anbo.2000.1255

Ramanna, M. S., Kuipers, A. G. J., and Jacobsen, E. (2003). Occurrence of numerically unreduced $(2 \mathrm{n})$ gametes in Alstroemeria interspecific hybrids and their significance for sexual polyploidisation. Euphytica 133, 95-106. doi: 10.1023/A:1025652808553

Rouiss, H., Bakry, F., Froelicher, Y., Navarro, L., Aleza, P., and Ollitrault, P. (2018). Origin of C. latifolia and C. aurantiifolia triploid limes: the preferential disomic inheritance of doubled-diploid "Mexican" lime is consistent with an interploid hybridization hypothesis. Ann. Bot. 121, 571-585. doi: $10.1093 / \mathrm{aob} / \mathrm{mcx} 179$

Rouiss, H., Cuenca, J., Navarro, L., Ollitrault, P., and Aleza, P. (2017a). Tetraploid citrus progenies arising from FDR and SDR unreduced pollen in $4 \mathrm{x} \times 2 \mathrm{x}$ hybridizations. Tree Genet. Genomes 13, 10. doi: 10.1007/s11295-016-1094-8

Rouiss, H., Cuenca, J., Navarro, L., Ollitrault, P., and Aleza, P. (2017b). Unreduced megagametophyte production in lemon occurs via three meiotic mechanisms, predominantly second-division restitution. Front. Plant Sci. 8, 1211. doi: 10.3389/fpls.2017.01211

Rounsaville, T. J., Touchell, D. H., and Ranney, T. G. (2011). Fertility and reproductive pathways in diploid and triploid miscanthus sinensis. HortScience 46, 1353-1357. doi: 10.21273/HORTSCI.46.10.1353

Schindelin, J., Rueden, C. T., Hiner, M. C., and Eliceiri, K. W. (2015). The ImageJ ecosystem: An open platform for biomedical image analysis. Mol. Reprod. Dev. 82, 518-529. doi: 10.1002/mrd.22489

Seker, M., Tuzcu, O., and Ollitrault, P. (2003). Comparison of nuclear DNA content of citrus rootstock populations by flow cytometry analysis. Plant Breed. 122, 169-172. doi: 10.1046/j.1439-0523.2003.00821.x

Sora, D., Kron, P., and Husband, B. C. (2016). Genetic and environmental determinants of unreduced gamete production in Brassica napus, Sinapis arvensis and their hybrids. Heredity 117, 440-448. doi: 10.1038/hdy.2016.69

Souza, M. M., Palomino, G., Pereira, T. N. S., Pereira, M. G., and Viana, A. P. (2004). Flow cytometric analysis of genome size variation in some Passiflora species. Hereditas 141, 31-38. doi: 10.1111/j.1601-5223.2004.01739.x

Stehlik, I., Kron, P., Barrett, S. C. H., and Husband, B. C. (2007). Sexing pollen reveals female bias in a dioecious plant. New Phytol. 175, 185-194. doi: 10.1111/j.1469-8137.2007.02093.x

Tanaka, T. (1954). Species Problem in Citrus (Revisio aurantiacearum, IX). Tokyo, Japan: Japanese Society for the Promotion of Science.

Tanaka, T. (1977). Fundamental discussion of Citrus classification. Stud Citrol. 14, 1-6.

Tavoletti, S., Pesaresi, P., Barcaccia, G., Albertini, E., and Veronesi, F. (2000). Mapping the jp (jumbo pollen) gene and QTLs involved in multinucleate microspore formation in diploid alfalfa. Theor. Appl. Genet. 101, 372-378. doi: $10.1007 / \mathrm{s} 001220051493$

Van Tuyl, J. M., de Vries, J. N., Bino, R. J., and Kwakkenbos, T. A. M. (1989). Identification of $2 \mathrm{n}$-pollen producing interspecific hybrids of Lilium using flow cytometry. Cytologia (Tokyo) 54, 737-745. doi: 10.1508/cytologia.54.737

Volk, G. M. (2011). "Chapter 25: Collecting pollen for genetic resources conservation," in Collecting Plant Diversity: Technical Guidelines. eds. L. Guarino, V. Ramanatha Rao, and E. Golbert (Fort Collins, USA: CAB International), 1-10.

Wang, J., Li, D., Shang, F., and Kang, X. (2017). High temperature-induced production of unreduced pollen and its cytological effects in Populus. Sci. Rep. 7, 5281. doi: 10.1038/s41598-017-05661-x

Yuan, Y., Lee, H., Hu, H., Scheben, A., and Edwards, D. (2018). Single-cell genomic analysis in plants. Genes (Basel). 9, 50. doi:10.3390/genes9010050.

Zhang, L., Cui, X., Schmitt, K., Hubert, R., Navidi, W., and Arnheim, N. (1992). Whole genome amplification from a single cell: implications for genetic analysis. Proc. Natl. Acad. Sci. U. S. A. 89, 5847-5851. doi: 10.1073/pnas.89.13.5847

Conflict of Interest Statement: The authors declare that the research was conducted in the absence of any commercial or financial relationships that could be construed as a potential conflict of interest.

Copyright (C) 2019 Garavello, Cuenca, Dreissig, Fuchs, Houben and Aleza. This is an openaccess article distributed under the terms of the Creative Commons Attribution License (CC BY). The use, distribution or reproduction in other forums is permitted, provided the original author(s) and the copyright owner(s) are credited and that the original publication in this journal is cited, in accordance with accepted academic practice. No use, distribution or reproduction is permitted which does not comply with these terms. 